\title{
Prevalence of bacteriophages infecting Staphylococcus aureus in dairy samples and their potential as biocontrol agents
}

\author{
P. García, ${ }^{* 1}$ C. Madera, ${ }^{*}$ B. Martínez, ${ }^{*}$ A. Rodríguez, ${ }^{*}$ and J. Evaristo Suárez† \\ *Instituto de Productos Lácteos de Asturias (IPLA-CSIC), Apdo. 85, 33300 Villaviciosa, Asturias, Spain \\ †Área de Microbiología, Facultad de Medicina, Universidad de Oviedo, Spain
}

\begin{abstract}
The prevalence of bacteriophages infecting Staphylococcus aureus in dairy samples was assessed. Fourteen Staph. aureus strains were used in enrichment cultures of 75 dairy samples. All samples grew specific Staph. aureus bacteriophages. According to the host range, 8 different phages were isolated. Three of them, phages $\Phi \mathrm{H} 5, \Phi \mathrm{G} 7$, and $\Phi \mathrm{A} 72$, were found in $89 \%$ of the samples; all the isolated phages were temperate. Phages $\Phi H 5$ and $\Phi A 72$ were used in preliminary bacterial challenge tests against Staph. aureus in milk. A phage mixture (1:1) was more effective than each single phage, most likely by preventing the survival of lysogenized cells. Phages inhibited Staph. aureus in UHT and pasteurized whole-fat milk. However, the phages were less active in semi-skimmed raw milk and little inhibition was achieved in whole, raw milk. Killing of Staph. aureus was observed at room temperature and at $37^{\circ} \mathrm{C}$, but not at refrigeration temperature.
\end{abstract}

Key words: bacteriophage, dairy product, Staphylococcus aureus, biocontrol

\section{INTRODUCTION}

Staphylococcus aureus is a relevant pathogen to the food processing industry because of the ability of some strains to produce heat-stable enterotoxins and other virulence factors that cause staphylococcal food poisoning (Dinges et al., 2000; Le Loir et al., 2003). In France, for instance, 25 out of 149 foodborne staphylococcal outbreaks that occurred in 1999 were attributed to the consumption of raw milk cheeses, and 3 out of 13 were also reported in Italy (WHO, 2000). A mass outbreak of staphylococcal poisoning was reported in Japan caused by the consumption of reconstituted skimmed milk (Ikeda et al., 2005).

Received September 24, 2008

Accepted March 3, 2009.

${ }^{1}$ Corresponding author: pgarcia@ipla.csic.es
Staphylococcus aureus is also a frequent cause of IMI in dairy cows (Gruet et al., 2001) and may consequently contaminate milk. Mastitis caused by Staph. aureus is a major concern because of its resistance to antibiotic treatment and its propensity to recur (Makovec and Ruegg, 2003). Growing concerns about antibiotic resistance have stimulated research into alternative treatment methods (Skurnik and Strauch, 2006).

Bacteriophages (viruses of bacteria) were investigated as antibacterial agents as far back as the 1920s as a means of eliminating bacteria, including staphylococci, in human infections. These efforts resulted in a wide range of phage therapy research results, which have been comprehensively reviewed (Kutter and $\mathrm{Su}-$ lakvelidze, 2005).

Bacteriophages have been also used as bactericidal agents in foods (Hudson et al., 2005). The FDA has recently approved the use of Listeria monocytogenes phage, Listex P100 (EBI Food Safety, Wageningen, the Netherlands) as GRAS (generally recognized as safe) for all food products (FDA, 2006). In milk and dairy products, phages have been successfully applied to prevent Salmonella Enteritidis development during Cheddar cheese manufacture and storage (Modi et al., 2001), Listeria monocytogenes growth in red smear cheeses (Carlton et al., 2005), and Staph. aureus proliferation in curd manufacturing processes (García et al., 2007). Therefore, there is clearly renewed interest in the exploitation of phages as antibacterial agents, with many pathogenic bacteria being targeted (Hagens and Loessner, 2007; Hanlon, 2007).

The objective of this study was to isolate a representative collection of bacteriophages of dairy origin infecting Staph. aureus as a preliminary approach to develop phage-based antimicrobial strategies with future applications in food biopreservation. With this in mind, we have used bovine Staph. aureus strains isolated from mastitic milk samples as hosts to assess the prevalence of Staph. aureus phages in the dairy environment. Finally, preliminary assays were performed to test the effectiveness of a phage mixture to inhibit Staph. aureus growth in milk. 
Table 1. Random amplification of polymorphism DNA (RAPD) profile of isolated bovine Staphylococcus aureus strains and efficiency of plaque formation (EOP) of phages $\Phi H 5$ and $\Phi$ A72

\begin{tabular}{llcc}
\hline & & \multicolumn{2}{c}{ EOP } \\
\cline { 3 - 4 } $\begin{array}{l}\text { Staph. aureus } \\
\text { strain }\end{array}$ & $\begin{array}{l}\text { RAPD } \\
\text { profile }^{1}\end{array}$ & $\Phi H 5$ & $\Phi$ A72 \\
\hline Sa1 & A & $0.72 \pm 0.03$ & $1.01 \pm 0.07$ \\
Sa2 & A & 0 & $0.39 \pm 0.02$ \\
Sa3 & B & 0 & $1.02 \pm 0.18$ \\
Sa4 & A & 0 & $1.32 \pm 0.06$ \\
Sa5 & C & 0 & 0 \\
Sa8 & C & 0 & 0 \\
Sa9 & D & $1 \pm 0.05$ & $1 \pm 0.1$ \\
Sa10 & E & 0 & 0 \\
Sa11 & E & 0 & $0.26 \pm 0.05$ \\
Sa12 & E & 0 & 0 \\
Sa13 & E & 0 & 0 \\
Sa14 & E & 0 & 0 \\
Sa15 & E & 0 & 0 \\
Sa16 & E & 0 & 0 \\
\hline
\end{tabular}

${ }^{1}$ Strains within a RAPD group shared more than $90 \%$ similarity.

\section{MATERIALS AND METHODS}

\section{Bacterial Strains and Growth Conditions}

Bovine Staph. aureus strains used for bacteriophage isolation and determination of host range were previously isolated from milk samples of mastitic cows belonging to different farms (Table 1). Eight Staph. aureus isolates from conventional bulk tank and organic milk (laboratory collection) were also used for phage host range determination (Table 2). Staphylococcal cells were cultured in $2 \mathrm{xYT}$ broth (Sambrook et al., 1989) using routine methods.

\section{Staphylococcal Strain Typing}

Bovine Staph. aureus strains were typed by random amplification of polymorphic DNA (RAPD)-PCR using the oligonucleotide RAPD5 from the RAPD Analy- sis Primer Set (Amersham Biosciences Europe GmbH, Madrid, Spain). Amplification conditions were $5 \mathrm{~min}$ at $95^{\circ} \mathrm{C}, 35$ cycles of $1 \mathrm{~min}$ at $95^{\circ} \mathrm{C}, 1 \mathrm{~min}$ at $32^{\circ} \mathrm{C}, 2 \mathrm{~min}$ at $72^{\circ} \mathrm{C}$, and a final $10-$ min extension step at $72^{\circ} \mathrm{C}$. The RAPD-PCR band patterns were scanned with the Gel Doc 2000 Gel Documentation System equipped with Quantity One software (BioRad Laboratories, Hercules, CA). Sorensen's similarity coefficient was calculated as a function of the presence/absence of the different bands for each pattern, different patterns being grouped using the unweighted pair group method with arithmetic averages (Priest and Austin, 1995).

\section{Bacteriophage Enrichment and Isolation}

Bulk tank milk from 72 collaborative farms in the Principado de Asturias (northern Spain), and 3 traditional cheeses manufactured in 3 different factories were used for bacteriophage screening purposes. Each milk $(100 \mu \mathrm{L})$ and cheese sample $(500 \mathrm{mg})$ was added to 2 $\mathrm{mL}$ of a bovine Staph. aureus strain (Table 2) growing in $2 \mathrm{xYT}$ containing $10 \mathrm{mg} / \mathrm{L} \mathrm{CaCl}_{2}$ and $10 \mathrm{mg} / \mathrm{L}$ $\mathrm{MgSO}_{4}$. The cultures were incubated overnight at $37^{\circ} \mathrm{C}$ with shaking. Samples were centrifuged at $13,000 \times g$ for $5 \mathrm{~min}$ and filtered. The supernatants were subjected to plaque assays using each of the 14 strains as indicators. Plaques were reisolated, propagated, and stored at $-80^{\circ} \mathrm{C}$ in SM buffer $(20 \mathrm{mg} / \mathrm{L}$ Tris $\mathrm{HCl}, 10 \mathrm{mg} / \mathrm{L}$ $\mathrm{MgSO}_{4}, 10 \mathrm{mg} / \mathrm{L} \mathrm{CaCl} 2,100 \mathrm{mg} / \mathrm{L} \mathrm{NaCl}, \mathrm{pH}$ 7.5) containing $50 \%$ glycerol ( $\mathrm{vol} / \mathrm{vol}$ ). Phages were purified by ultracentrifugation $(100,000 \times g$ for $90 \mathrm{~min})$ followed by $\mathrm{CsCl}$ continuous gradient centrifugation (Sambrook et al., 1989).

\section{Bacteriophage Host Range}

The host range of phages was determined by the plaque assay: a $0.1-\mathrm{mL}$ volume of stationary-phase host

Table 2. Staphylococcus aureus bacteriophages selected in this study along with their respective source and host range

\begin{tabular}{|c|c|c|c|c|c|}
\hline Phage & Temperate & Source & $\begin{array}{c}\text { No. of } \\
\text { samples } \\
(\mathrm{n}=75)\end{array}$ & \multicolumn{2}{|r|}{ Host range $^{2}$} \\
\hline$\Phi \mathrm{C} 1$ & + & Cabrales cheese & 3 & $\underline{\text { Sa1 }}$ & GDC6 \\
\hline$\Phi \mathrm{L} 7$ & + & Milk & 1 & $\underline{\underline{\mathrm{Sa} 3}}$ & AC9, FG1, AC11, GDC6, GRA16 \\
\hline$\Phi L 13$ & + & Milk & 1 & $\overline{\mathrm{Sa} 1}, \mathrm{Sa} 2, \underline{\mathrm{Sa} 4}, \mathrm{Sa} 9$ & $\mathrm{AC} 9, \mathrm{DC} 6$ \\
\hline$\Phi \mathrm{A} 8$ & + & Milk & 2 & $\mathrm{Sa} 1, \underline{\mathrm{Sa} 2}, \overline{\mathrm{Sa} 9}, \mathrm{Sa} 11$ & - \\
\hline$\Phi \mathrm{A} 72$ & + & Milk & 21 & $\mathrm{Sa} 1, \mathrm{Sa} 2, \overline{\mathrm{Sa} 3}, \mathrm{Sa} 4, \underline{\mathrm{Sa} 9}, \mathrm{Sa} 11$ & AC9, AFG1, AC11, GDC3, GDC6, GRA16, JFL2, JFL6 \\
\hline
\end{tabular}

${ }^{1}$ Number of samples in which each phage was isolated.

${ }^{2}$ Staph. aureus strains used in the enrichment cultures to isolate each phage are underlined; — indicates that none of the strains was infected by the given phage. 
culture $\left(10^{9} \mathrm{cfu} / \mathrm{mL}\right)$ was mixed with several dilutions of individual phage suspensions in $3 \mathrm{~mL}$ of molten $2 \mathrm{xYT}$ top agar $(0.7 \%$ agar) and the mixture was poured on $2 \mathrm{xYT}$ agar plates. Efficiency of plaque formation (EOP) of selected phages was determined by dividing the phage titer on the test strain by the phage titer on the reference strain Staph. aureus Sa9. This strain was selected because it is infected by most of the isolated phages (see Results section, Table 2).

\section{Temperate Versus Lytic Phage Determination}

To determine if a phage was temperate, putative lysogens (resistant to infection) were isolated from lysis plaques. For each phage, several plaques were scratched and viable cells were colony-isolated on $2 \mathrm{xYT}$ agar plates. Twenty isolated colonies were challenged by the plaque assay with the corresponding phage to confirm resistance to infection. Additionally, exponentially growing cultures were subsequently induced by adding mitomycin $\mathrm{C}(0.5 \mu \mathrm{g} / \mathrm{mL})$ to confirm prophage release. After incubation at $37^{\circ} \mathrm{C}$ for $4 \mathrm{~h}$ with shaking, supernatants were filtered and tested by the plaque assay against all the staphylococcal strains to verify the host range of the phage.

\section{Cross-Immunity Assays}

Staphylococcus aureus Sa9 was lysogenized by phages $\Phi H 5$ or $\Phi$ A72 as described (see previous section). Once it was confirmed that the phage was integrated in the chromosome, cross-immunity was assessed by the spot test. Plates were prepared by adding $100 \mu \mathrm{L}$ of an overnight culture of the lysogenic strain to $5 \mathrm{~mL}$ of molten $2 \mathrm{xYT}$ agar $(0.7 \%)$. A $3-\mu \mathrm{L}$ volume of the phage stock $\left(10^{9} \mathrm{pfu} / \mathrm{mL}\right)$ was spotted onto the surface. Plates were incubated at $37^{\circ} \mathrm{C}$ for $18 \mathrm{~h}$ and checked for clearing zones.

\section{Phage Temperature Stability}

Phage stocks were diluted in UHT whole-fat milk to obtain $10^{5}$ and $10^{7} \mathrm{pfu} / \mathrm{mL}$. The suspensions were incubated at 4,22 , and $37^{\circ} \mathrm{C}$ for $8 \mathrm{~h}$ and the phage titer was determined. Similarly, phage suspensions were incubated at $72^{\circ} \mathrm{C}$ and samples were removed at $15 \mathrm{~s}$, and $1,3,5$, and 15 min for phage titration.

\section{Phage Antimicrobial Activity in Milk}

The effect of phage infection on Staph. aureus growth was tested in commercial UHT and pasteurized wholefat milk, and in whole-fat and semi-skimmed raw milks (which were centrifuged at $6,000 \times g$ for $20 \mathrm{~min}$ to re- move part of the fat) supplied by a collaborating farm. Milk was inoculated with diluted overnight cultures of Staph. aureus $\mathrm{Sa} 9\left(10^{2} \mathrm{cfu} / \mathrm{mL}\right)$ and the phages $\Phi \mathrm{H} 5$ and $\Phi A 72\left(10^{4}\right.$ to $\left.10^{5} \mathrm{pfu} / \mathrm{mL}\right)$. The mixtures were incubated at $37^{\circ} \mathrm{C}$ without shaking. In experiments simulating a breakdown in refrigerated storage, UHT whole-fat milk was inoculated with diluted overnight cultures of Staph. aureus $\mathrm{Sa} 9\left(10^{2} \mathrm{cfu} / \mathrm{mL}\right)$ and a mixture of phages $\Phi \mathrm{H} 5$ and $\Phi A 72\left(10^{1}, 10^{2}\right.$, and $\left.10^{4} \mathrm{pfu} / \mathrm{mL}\right)$. The mixtures were incubated at $4^{\circ} \mathrm{C}$ for $18 \mathrm{~h}$ and then shifted to $22^{\circ} \mathrm{C}$ for the following $30 \mathrm{~h}$. In all experiments, samples were taken at different time intervals and scored for Staph. aureus on Chapman agar plates (Scharlau Chemie S.A., Barcelona, Spain) and for phages using the plaque assay. The absence of Staph. aureus in noninoculated milk was verified by direct plating.

\section{Statistical Analysis}

Results were compared by one-way ANOVA analysis using the SPSS 11.0 software for Windows (SPSS Inc., Chicago, IL). Experiments were performed in triplicate.

\section{RESULTS AND DISCUSSION}

\section{Bacteriophage Prevalence in Dairy Samples}

We proceeded to isolate, from the dairy environment, new staphylococcal phages that might be better adapted and, therefore, more effective for biocontrol purposes in milk and dairy products. Fourteen Staph. aureus strains previously isolated from mastitic milk samples and RAPD-typed were used as hosts in enrichments assays to detect phages able to infect Staph. aureus in dairy samples. These strains were grouped into 5 clusters (A to E) with a similarity $>90 \%$ within a cluster (Figure 1, Table 1). The enrichment procedure was a very efficient method for phage isolation, and phages were detected in all the dairy samples tested (72 raw milk samples and 3 cheeses). At this step, only phages able to infect the strain used in enrichment cultures were selected for further assays. In this way, any potential prophage released from the staphylococcal strains used as hosts was discarded. It is important to note that different host ranges were revealed when phages were plated on several strains of mastitic and dairy origin, but no correlation to the RAPD grouping was observed (i.e., strains belonging to the same RAPD profile showed a distinct phage susceptibility pattern). According to the host range, 8 different phages (2 from artisan cheeses and 6 from raw milk) were obtained (Table 2). A few phages were predominant in the dairy environment studied. In our screening, $89 \%$ of the samples contained 


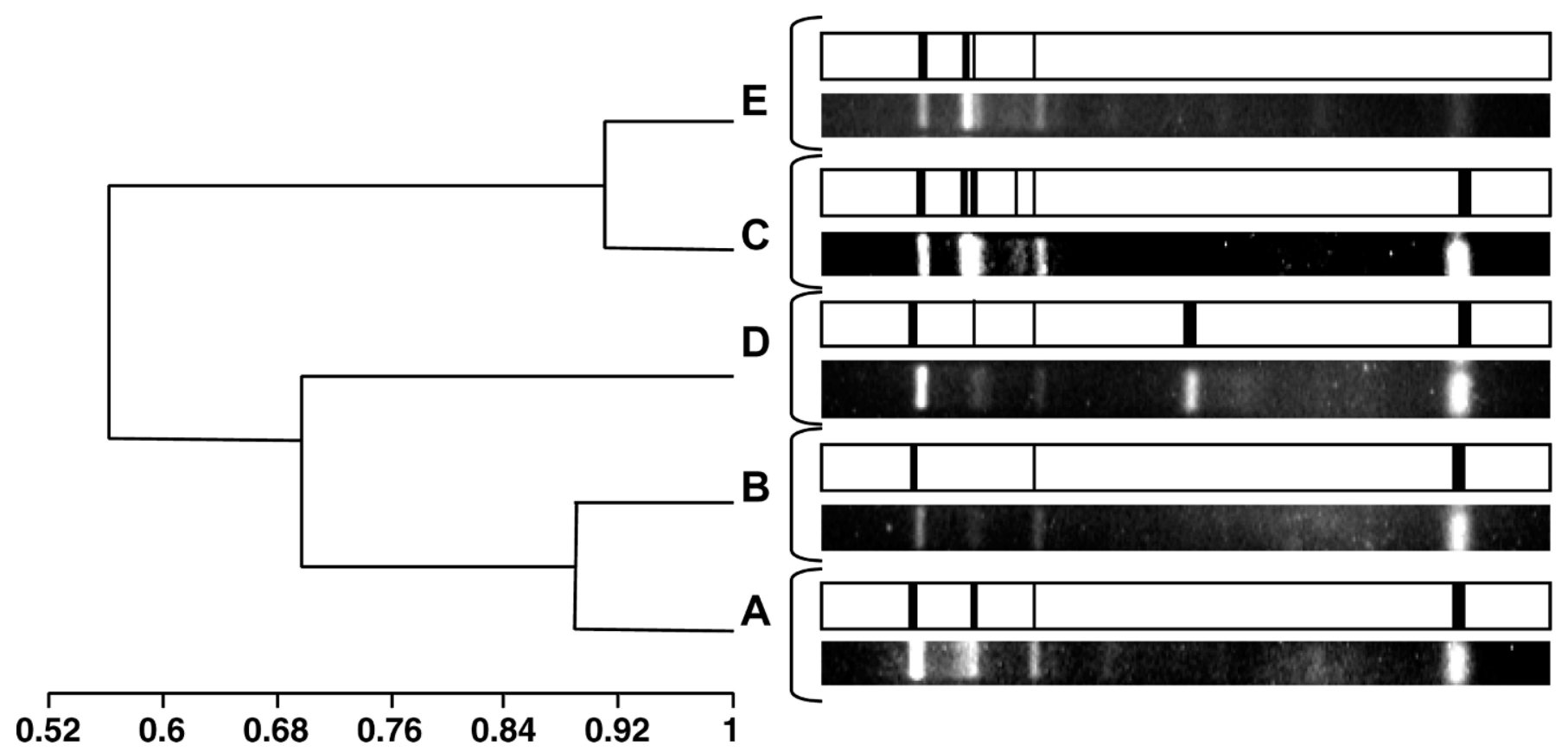

Figure 1. Random amplification of polymorphic DNA (RAPD)-PCR profiles of bovine Staphylococcus aureus isolates obtained with the oligonucleotide RAPD5 and the similarity dendrogram generated by the unweighted pair group method with arithmetic averages.

one of the $\Phi H 5, \Phi \mathrm{G} 7$, or $\Phi \mathrm{A} 72$ phages, which were detected in 26,21 , and 20 dairy samples, respectively. Some of the phages were very specific, infecting only one of the panel strains, whereas others, such as $\Phi$ A72, infected a much wider range that included both mastitic and milk-derived staphylococcal strains (Table 2). The complete set of isolated phages was able to infect all our mastitic strains, and a suitable mixture of these phages would, theoretically, inhibit the major clonal staphylococcal types associated with mastitis in our region and, consequently, the main source of staphylococcal contamination in milk.

However, none of the selected phages was able to generate plaques on any of 13 Staph. aureus from human clinical samples (data not shown), suggesting that the livestock and human strains could be differentiated by typing with these phages. Similar results were obtained with phages CS1 and DW2 isolated from farmyard slurry (O'Flaherty et al., 2005b). Thus, the origin of phages should also be taken into account when designing either a biopreservative or a therapeutic preparation for humans.

All these newly isolated phages were temperate, because lysogenic bacteria were easily isolated from the clearing zones (Table 2). This seems to be a general feature within phages infecting Staph. aureus (Kwan et al., 2005). Temperate phages may be involved in lysogenic conversion and horizontal transfer of undesirable traits. Thus, their genetic content, their transduc- tion ability, as well as their putative contribution to host fitness should be carefully analyzed before their use as biocontrol agents in food. However, because of the genetic amenability of phages, undesirable traits could be changed or deleted. Based on this, their lysogenic nature per se should not immediately preclude their potential use as antimicrobials, as reviewed by Matsuzaki et al. (2005) and Mann (2008).

Two phages, $\Phi H 5$ and $\Phi A 72$, were selected to assess their antimicrobial potential in milk on the basis of their broad host range, which comprised most of the mastitic and dairy strains (Table 2). The morphology of their virions under electron microscopy showed isometric capsids and long noncontractile flexible tails typical of the Siphoviridae family as described recently (García et al., 2007). Their EOP, where the efficiency of strain Staph. aureus Sa9 is taken to be 1.0, ranged from 0 to 1.32 (Table 1 ).

\section{Temperature Stability of Phages $\Phi \mathrm{H} 5$ and $\Phi$ A72 in Milk}

The stability in milk of these phages was tested at different temperatures. Similar phage titers were maintained at $4^{\circ} \mathrm{C}$ for $8 \mathrm{~h}$, confirming that 0 to $5^{\circ} \mathrm{C}$ is the most suitable range for phage stability (Civerolo, 1990). Incubations at 22 and $37^{\circ} \mathrm{C}$ resulted in 20 to $30 \%$ phage inactivation. Both phages withstood very short exposures at higher temperatures $\left(72^{\circ} \mathrm{C}, 15 \mathrm{~s}\right)$ but the 
Table 3. Survival of $\Phi H 5$ and $\Phi A 72$ phage suspensions in UHT whole-fat milk during storage at different temperatures and heat treatment

\begin{tabular}{|c|c|c|c|c|}
\hline \multirow[b]{3}{*}{ Treatment $^{1}$} & \multicolumn{4}{|c|}{ Survival $^{2}(\%)$} \\
\hline & \multicolumn{2}{|c|}{$\Phi H 5$} & \multicolumn{2}{|c|}{$\Phi \mathrm{A} 72$} \\
\hline & $4 \times 10^{5} \mathrm{pfu} / \mathrm{mL}$ & $3 \times 10^{7} \mathrm{pfu} / \mathrm{mL}$ & $4 \times 10^{5} \mathrm{pfu} / \mathrm{mL}$ & $3 \times 10^{7} \mathrm{pfu} / \mathrm{mL}$ \\
\hline $4^{\circ} \mathrm{C}, 8 \mathrm{~h}$ & 100 & 100 & 100 & 100 \\
\hline $22^{\circ} \mathrm{C}, 8 \mathrm{~h}$ & 78 & 79 & 72 & 80 \\
\hline $37^{\circ} \mathrm{C}, 8 \mathrm{~h}$ & 73 & 75 & 70 & 78 \\
\hline $72^{\circ} \mathrm{C}, 15 \mathrm{~s}$ & 86 & 98 & 93 & 99 \\
\hline $72^{\circ} \mathrm{C}, 1 \mathrm{~min}$ & 0 & 0 & 0 & 0 \\
\hline $72^{\circ} \mathrm{C}, 3 \mathrm{~min}$ & 0 & 0 & 0 & 0 \\
\hline $72^{\circ} \mathrm{C}, 5 \min$ & 0 & 0 & 0 & 0 \\
\hline $72^{\circ} \mathrm{C}, 15 \min$ & 0 & 0 & 0 & 0 \\
\hline
\end{tabular}

${ }^{1}$ Two initial phage concentrations $\left(4 \times 10^{5}\right.$ and $\left.3 \times 10^{7} \mathrm{pfu} / \mathrm{mL}\right)$ were used.

${ }^{2}$ Survival was defined as $\mathrm{pfu} / \mathrm{mL}$ after the treatment divided by the initial $\mathrm{pfu} / \mathrm{mL}$.

titer was reduced to below the limit of detection $(<10$ $\mathrm{pfu} / \mathrm{mL}$ ) after $1 \mathrm{~min}$ of exposure (Table 3$)$. It would be expected, therefore, that mixtures of these phages will not be fully inactivated by current pasteurization processes and then might inhibit Staph. aureus growth during manufacture of dairy products. Resistance of phages to pasteurization has already been described (Madera et al., 2004).

\section{Absence of Cross-Immunity Between $\Phi H 5$ and $\Phi A 72$}

The ability of phages to lysogenize might hinder the use of phages as biocontrol agents. Lysogenized strains, whereby the resident repressor blocks the replication of the infecting phage, become immune to infection by similar phages (Ladero et al., 1998). However, the use of a complex mixture of several phages would minimize the risk. To test this, lysogenic cultures to each phage were generated (Staph. aureus Sa9 lysH5 and Staph. aureus Sa9 lysA72, respectively). Staphylococcus aureus Sa9 lysH5 was resistant to infection by phage $\Phi \mathrm{H} 5$ but was infected and lysed by phage $\Phi$ A72. Likewise, Staph. aureus Sa9 lysA72 cells containing $\Phi \mathrm{A} 72$ as a prophage were immune to $\Phi \mathrm{A} 72$ but susceptible to $\Phi \mathrm{H} 5$ infection. Based on these results, $\Phi \mathrm{A} 72$ and $\Phi \mathrm{H} 5$ belong to a distinct immunity group and, thus, suitable mixtures of these phages would prevent the development of lysogenic derivative strains. Alternatively, another feasible strategy would be to obtain lytic derivative phages unable to lysogenize (García et al., 2007).

\section{Antimicrobial Activity of Phages in Milk}

Preliminary challenge trials were performed in UHT whole-fat milk to assess the ability of the phages to lyse Staph. aureus Sa9 individually or in combination. The growth of Staph. aureus was inhibited regardless of whether single phages or a combination were used (Figure 2). However, the mixture was significantly more efficient $(P<0.05)$, most likely by preventing the selection of bacteriophage-insensitive mutants and lysogenic derivatives.

Staphylococcus aureus Sa9 was also challenged with the phage mixture in pasteurized, semi-skimmed, and whole-fat raw milks to determine to what extent commonly used milk treatment procedures (i.e., heating and skimming) affected the ability of the phages to inhibit Staph. aureus (Figure 3). In pasteurized whole-fat milk, the Staph. aureus population was $3.6 \log$ units lower than the control culture without phages at the end of the incubation period. Accordingly, the phage titer increased with time (Figure 3A). An earlier effect of the phage mixture on Staph. aureus growth was observed in semi-skimmed raw milk because lower staphylococcal counts were detected compared with the control culture after $4 \mathrm{~h}$ of incubation. Differences were significant $(P<$ 0.05 ) throughout the incubation period (Figure $3 \mathrm{~B}$ ). In contrast, the antibacterial activity of the phage mixture was clearly reduced in whole-fat raw milk (Figure 3C). Nevertheless, significantly lower counts were observed $(P<0.05)$ after $11 \mathrm{~h}$. It is worth noting that in all cases, the phage mixture kept Staph. aureus counts low enough to avoid toxin accumulation over concentrations that cause food intoxication (Waldvogel, 2001), even in raw milk. This would be of great relevance to the food industry, as it would prevent accumulation of toxins that are not easily inactivated by heat treatments.

In all tested conditions, total clearance of Staph. aureus in milk was not achieved. This might be expected because of the very low phage/cell ratio used in the experiments or because of resistance development. It is widely recognized that at low cell densities, larger numbers of phages are required to ensure efficient infection (Kasman et al., 2002). The antibacterial activity of 


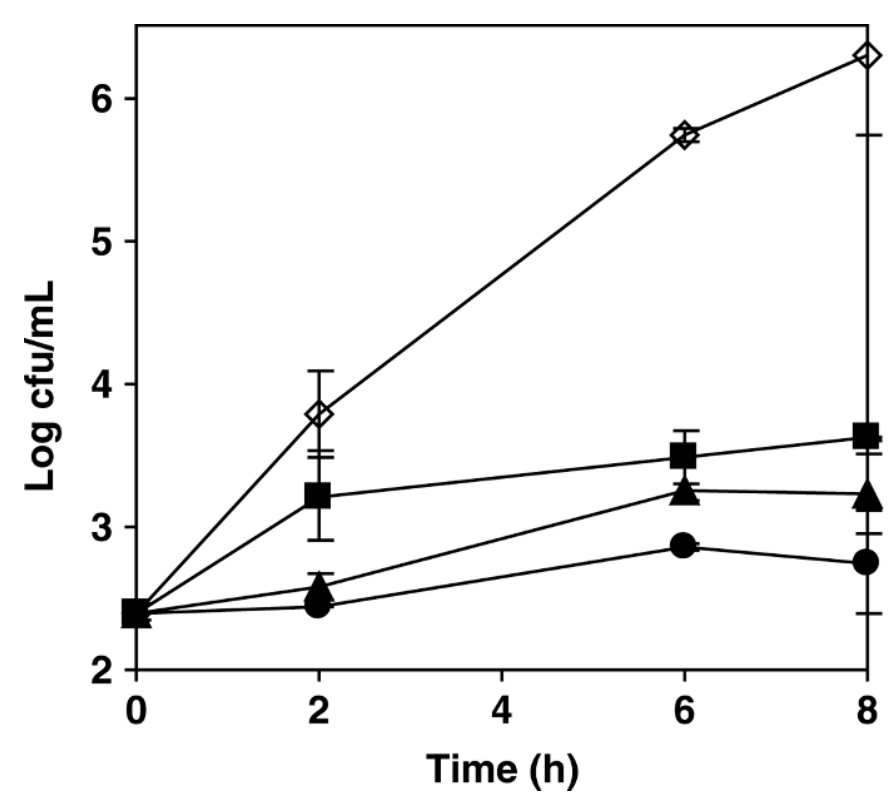

Figure 2. Inhibitory activity of single phages and the phage mixture $\left(10^{4}\right.$ to $\left.10^{5} \mathrm{pfu} / \mathrm{mL}\right)$ against Staphylococcus aureus $\mathrm{Sa} 9$ at $37^{\circ} \mathrm{C}$ in UHT whole-fat milk: $\diamond=$ Staph. aureus, $\mathbf{\square}=$ Staph. aureus $+\Phi \mathrm{A} 72, \boldsymbol{\Delta}$ $=$ Staph. aureus $+\Phi \mathrm{H} 5, \bullet=$ Staph. aureus $+\Phi \mathrm{A} 72+\Phi \mathrm{H} 5$.

the phages could also be reduced by the slow growth of Staph. aureus in both raw milks, likely because of the antagonistic and competitive effect of milk microbiota. Furthermore, the complexity linked to untreated raw milks may hinder phage diffusion. This will clearly hinder the chance of a phage encountering its host.

We observed that phage titer decreased about $1 \log$ unit throughout the incubation period in semi-skimmed and whole-fat raw milk assays (Figure 3B and Figure $3 \mathrm{C})$. This could indicate partial inactivation of the phages and their progeny in unheated milks. The raw milk used in these assays was not homogenized, in con- trast to the commercial UHT and pasteurized milks. Thus, fat globules and milk protein might aggregate phage particles and render them unable to infect the host under the assay conditions. Similar inactivation in raw milk has been described for bacteriophage $\mathrm{K}$ (O'Flaherty et al., 2005a; Gill et al., 2006). A more detailed analysis should be carried out to determine whether milk components protect cells from infection or the phages themselves are inactivated.

\section{Antimicrobial Activity of Phages in Milk Under Storage and Breakdown Temperature}

Because development of Staph. aureus is usually a consequence of a breakdown in the cold chain during milk processing, we also tested how phages influence the growth of the pathogen under refrigeration conditions followed by a shift to a warmer incubation. Refrigerated milk was contaminated with Staph. aureus Sa9 $\left(10^{2} \mathrm{cfu} / \mathrm{mL}\right)$ and a phage mixture $(\Phi \mathrm{H} 5+\Phi \mathrm{A} 72)$ at $10^{1}, 10^{2}$, and $10^{4} \mathrm{pfu} / \mathrm{mL}$. Incubation was performed at $4^{\circ} \mathrm{C}$ for $18 \mathrm{~h}$ and the temperature was then increased to $22^{\circ} \mathrm{C}$ for the following $30 \mathrm{~h}$. During cold storage of milk, nonappreciable changes in the viable counts and phage titer occurred (Figure 4). The shift to a permissive temperature resulted in exponential development of Staph. aureus in both control and phage-infected milk cultures. Nevertheless, lower pathogen growth clearly dependent on the phage concentration was observed in phage-infected cultures for the first $24 \mathrm{~h}$ of incubation at $22^{\circ} \mathrm{C}$. At the end of the incubation period, however, a 5 -log-unit reduction in bacterial counts compared with the control was observed regardless of the initial phage concentration (Figure 4A). The phage titer was stable at refrigeration temperatures and increased sharply after $12 \mathrm{~h}$ of incubation at $22^{\circ} \mathrm{C}$. As previously reported

\section{A}

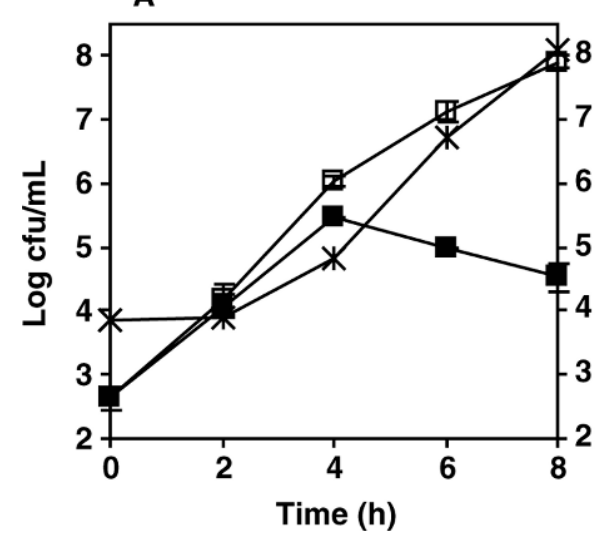

B

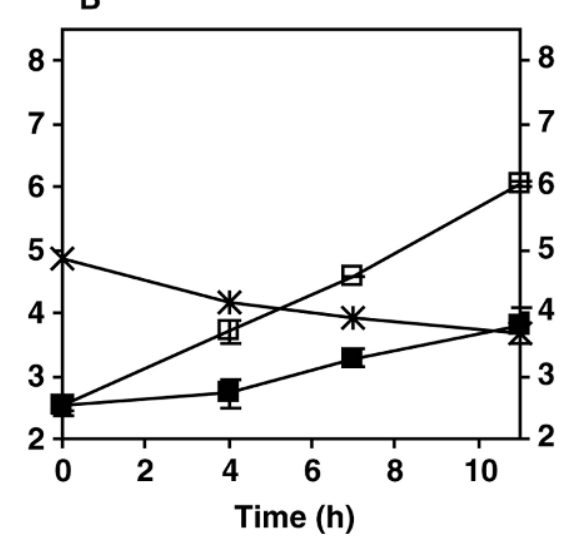

C

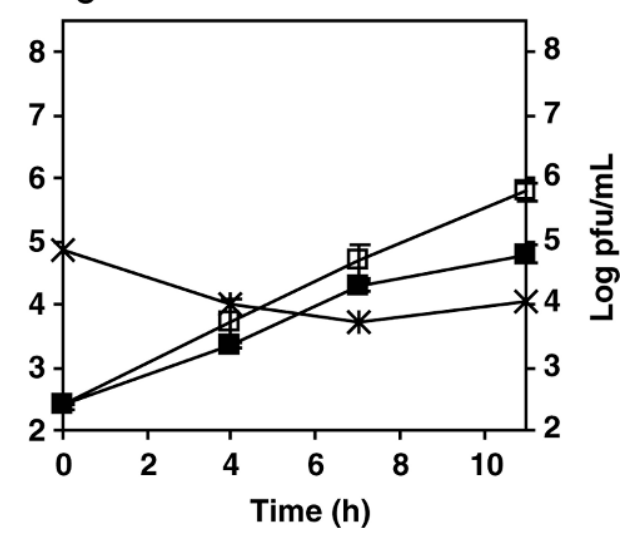

Figure 3. Antibacterial activity of phages $\Phi \mathrm{H} 5$ and $\Phi \mathrm{A} 72$ against Staphylococcus aureus Sa9 at $37^{\circ} \mathrm{C}$ in $\left.\mathrm{A}\right)$ pasteurized whole-fat milk, B) semi-skimmed raw milk, and C) whole-fat raw milk. $\square=$ Staph. aureus, $\mathbf{\square}=$ Staph. aureus $+\Phi \mathrm{A} 72+\Phi \mathrm{H} 5, \times=$ phage titer. 

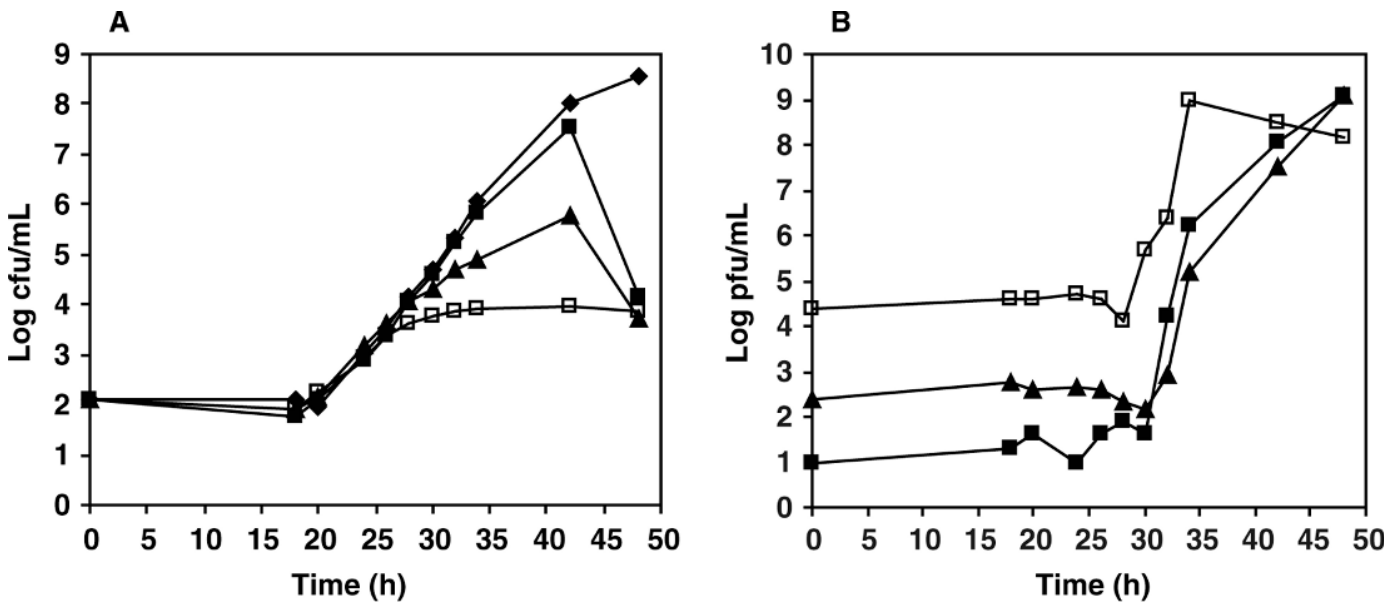

Figure 4. Inhibitory activity of a mixture of phages $\Phi H 5$ and $\Phi$ A72 against Staphylococcus aureus Sa9 in UHT whole-fat milk during a simulated breakdown in the cold chain. Incubation proceeded at $4^{\circ} \mathrm{C}$ for $18 \mathrm{~h}$, shifted to $22^{\circ} \mathrm{C}$, and was maintained there for $30 \mathrm{~h}$. A) Growth of

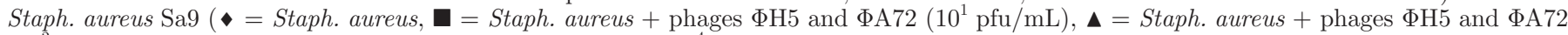
$\left(10^{2} \mathrm{pfu} / \mathrm{mL}\right), \square=$ Staph. aureus + phages $\Phi H 5$ and $\Phi$ A72 $\left.\left(10^{4} \mathrm{pfu} / \mathrm{mL}\right) ; B\right)$ titer of bacteriophages in samples in which phages were added at initial concentrations of $10^{1} \mathrm{pfu} / \mathrm{mL}(\mathbf{\square}), 10^{2} \mathrm{pfu} / \mathrm{mL}(\boldsymbol{\Lambda})$, or $10^{4} \mathrm{pfu} / \mathrm{mL}(\square)$.

(Cairns et al., 2009), phage propagation only occurred when Staph. aureus could multiply actively and reach a threshold bacterial concentration that allowed the phage titer to increase (Figure 4B). These results showed that bacteriophages might be used as an additional countermeasure against temperature breakdown.

\section{CONCLUSIONS}

Our findings suggest that the dairy environment is an extensive source of staphylococcal phages, which may be effective in certain milk types to inhibit staphylococcal strains that often cause mastitis and contaminate milk. However, all the isolated phages were temperate, a feature that may hinder their efficacy as biocontrol agents in food. The use of phage mixtures is advisable to cover a wider inhibitory spectrum and to avoid, at least to some extent, the development of resistance. Phages of dairy origin were shown to be suitable to counteract the harmful effects of temperature failure during milk processing and storage.

\section{ACKNOWLEDGMENTS}

This research study was supported by grants SAF20040033 and AGL2006-03659/ALI from the Ministry of Science and Technology (Spain) and the FEDER Plan and by the contracts CN-05-048 and CN-05-049 from Mercadona S.A. to Juan Evaristo Suárez. Pilar García is a fellow of the Spanish Ministry of Education Ramón y Cajal Research Programme. The authors thank Julián C. Rivas-Gonzalo and the Nutrition and Bromatology Unit (University of Salamanca, Spain) for hosting Pilar
García. We also thank LILA-Asturias-ALCE-Calidad (Asturias, Spain) for providing the dairy samples.

\section{REFERENCES}

Cairns, B. J., A. R. Timms, V. A. A. Jansen, I. F. Connerton, and R. J. H. Payne. 2009. Quantitative models of in vitro bacteriophagehost dynamics and their application to phage therapy. PLoS Pathog. 5:e1000253.

Carlton, R. M., W. H. Noordman, B. Biswas, E. D de Meester, and M. J. Loessner. 2005. Bacteriophage P100 for control of Listeria monocytogenes in foods: Genome sequence, bioinformatic analyses, oral toxicity study, and application. Regul. Toxicol. Pharmacol. 43:301-312.

Civerolo, E. L. 1990. Bacteriophages. Pages 205-213 in Methods in Phytobacteriology. Z. Klement, K. Rudolph, and D. C. Sands, ed. Akademiai Kiado, Budapest, Hungary.

Dinges, M. M., P. M. Orwin, and P. M. Schlievert. 2000. Exotoxins of Staphylococcus aureus. Clin. Microbiol. Rev. 13:16-64.

FDA. 2006. Food additives permitted for direct addition to food for human consumption; bacteriophage preparation. Fed. Regist. 71:47729-47732

García, P., C. Madera, B. Martínez, and A. Rodríguez. 2007. Biocontrol of Staphylococcus aureus in curd manufacturing processes using bacteriophages. Int. Dairy J. 17:1232-1239.

Gill, J. J., P. M. Sabour, K. E. Leslie, and M. W. Griffiths. 2006. Bovine whey proteins inhibit the interaction of Staphylococcus aureus and bacteriophage K. J. Appl. Microbiol. 101:377-386.

Gruet, P., P. Maicent, X. Berthelot, and V. Kaltsatos. 2001. Bovine mastitis and intramammary drug delivery: review and perspectives. Adv. Drug Deliv. Rev. 50:245-259.

Hagens, S., and M. J. Loessner. 2007. Application of bacteriophages for detection and control of foodborne pathogens. Appl. Microbiol. Biotechnol. 76:513-519.

Hanlon, G. W. 2007. Bacteriophages: An appraisal of their role in the treatment of bacterial infections. Int. J. Antimicrob. Agents 30:118-128.

Hudson, J. A., C. Billington, C. Carey-Smith, and G. Greening. 2005. Bacteriophages as biocontrol agents in food. J. Food Prot. $68: 426-437$.

Ikeda, T., N. Tamate, K. Yamaguchi, and S. Makino. 2005. Quantitative analysis of Staphylococcus aureus in skimmed milk powder by realtime PCR. J. Vet. Med. Sci. 67:1037-1041. 
Kasman, L. M., A. Kasman, C. Westwater, J. Dolan, M. G. Schmidt, and J. S. Norris. 2002. Overcoming the phage replication threshold: A mathematical model with implications for phage therapy. J. Virol. 76:5557-5564.

Kutter, E., and A. Sulakvelidze. 2005. Bacteriophages Biology and Applications. CRC Press, Boca Raton, FL.

Kwan, T., J. Liu, M. Dubow, P. Gros, and J. Pelletier. 2005. The complete genomes and proteomes of 27 Staphylococcus aureus bacteriophages. Proc. Natl. Acad. Sci. USA 102:5174-5179.

Ladero, V., P. García, V. Bascarán, M. Herrero, M. A. Álvarez, and J. E. Suárez. 1998. Identification of the repressor-encoding gene of the temperate bacteriophage A2. J. Bacteriol. 180:3474-3476.

Le Loir, Y., F. Baron, and M. Gautier. 2003. Staphylococcus aureus and food poisoning. Genet. Mol. Res. 2:63-76.

Madera, C., C. Monjardín, and J. E. Suárez. 2004. Milk contamination and resistance to processing conditions determine the fate of Lactococcus lactis bacteriophages in dairies. Appl. Environ. Microbiol. 70:7365-7371.

Makovec, J. A., and P. L. Ruegg. 2003. Antimicrobial resistance of bacteria isolated from dairy cow milk samples submitted for bacterial culture: 8,905 samples (1994-2001). J. Am. Vet. Med. Assoc. 222:1582-1589.

Mann, N. H. 2008. The potential of phages to prevent MRSA infections. Res. Microbiol. 159:400-405.

Matsuzaki, S., M. Rashel, J. Uchiyama, S. Sakurai, T. Ujihara, M. Kuroda, M. Ikeuchi, T. Tani, M. Fujieda, H. Wakiguchi, and S. Imai. 2005. Bacteriophage therapy: A revitalized therapy against bacterial infectious diseases. J. Infect. Chemother. 1:211-219.

Modi, R., Y. Hirvi, A. Hill, and M. W. Griffiths. 2001. Effect of phage on survival of Salmonella Enteritidis during manufacture and storage of Cheddar cheese made from raw and pasteurized milk. J. Food Prot. 64:927-933.

O'Flaherty, S., A. Coffey, W. J. Meaney, G. F. Fitzgerald, and R. P. Ross. 2005a. Inhibition of bacteriophage $\mathrm{K}$ proliferation on Staphylococcus aureus in raw bovine milk. Lett. Appl. Microbiol. 41:274-279.

O'Flaherty, S., R. P. Ross, J. Flynn, W. J. Meaney, G. F. Fitzgerald, and A. Coffey. 2005b. Isolation and characterization of two antistaphylococcal bacteriophages specific for pathogenic Staphylococcus aureus associated with bovine infections. Lett. Appl. Microbiol. 41:482-486.

Priest, F., and B. Austin. 1995. Numerical taxonomy. P. 14-49 in Modern Bacterial Taxonomy. F. Priest and B. Austin, ed. Chapman and Hall, London, UK.

Sambrook, J., T. Maniatis, and E. F. Fritsch. 1989. Molecular Cloning: A Laboratory Manual. 2nd ed. Cold Spring Harbor Laboratory Press, Cold Spring Harbor, NY.

Skurnik, M., and E. Strauch. 2006. Phage therapy: Facts and fiction. Int. J. Med. Microbiol. 296:5-14.

WHO (World Health Organization). 2000. Surveillance Report: Programme for Control of Foodborne Infections and Intoxications in Europe. 8th Report 1999-2000. http://www.bfr.bund.de/ internet/8threport/8threp_fr.htm.

Waldvogel, F. A. 2001. Staphylococcus aureus (including staphylococcal toxic shock), p. 2069-2092 in Principles and Practice of Infectious Diseases. J. L. Mandell, J. E. Bennett, and R. Dolin, ed. Churchill Livingstone, Philadelphia, PA. 